\title{
RANCANG BANGUN SISTEM INFORMASI PENGGAJIAN KARYAWAN PADA KOPERASI KARYAWAN PT GIKEN PRECISION INDONESIA
}

\author{
Mesgiyono ${ }^{1)}$, Riki, S.T., M.M ${ }^{2}$ \\ 1email:mesgiyono53@gmail.com \\ Program Studi Manajemen Informatika, STMIK GICI \\ 2email:riki.yasril@gmail.com \\ Program Studi Sistem Informasi, STMIK GICI
}

\begin{abstract}
Abstrak
Pembaruan teknologi dalam proses bisnis sangat diperlukan bagi Organisasi, salah satu pembaruan yang dapat ditingkatkan pada bagian penggajian. Koperasi Karyawan PT Giken Precision Indonesia membutuhkan sistem yang menunjang proses penggajian yang baik bagi para karyawannya, Sistem Penggajian yang ada pada Koperasi Karyawan PT Giken Precision Indonesia masih dilakukan secara manual, yaitu melakukan pencantatan data karyawan hingga pembuatan slip gaji, hal ini menimbulkan keterlambatan informasi dan kehilangan data. Untuk mengatasi masalah-masalah tersebut, diperlukan adanya sistem yang terkomputerisasi yang baru untuk meningkatkan efisiensi kerja. Metodologi yang dipakai untuk merancang sistem terkomputerisasi tersebut adalah : menganalisis sistem yang sedang berjalan, mendesain sistem baru, membuat sistem, dan yang terakhir menguji sistem yang telah dibuat. Aplikasi yang dihasilkan dalam pembuatan program ini adalah aplikasi sistem informasi penggajian karyawan dengan menggunakan bahasa pemrograman Visual Basic 2008 dan rancangan databasenya menggunakan MySql Server. Setelah melalui tahapan sesuai dengan metode pengembangan yang dipilih maka dalam pengimplementasian sistem informasi penggajian yaitu secara berkesinambungan dan memiliki tindak lanjut pengujian sistem yang terdiri dari pengujian dimana pengujian ini menggunakan metode pengujian black box yang berfokus pada persyaratan fungsional perangkat lunak dan pengujian betha yaitu pengujian lapangan dengan pengolahan data sebagai nilai akurasi hasil pilihan.
\end{abstract}

Kata Kunci : CrystalReport, Koperasi, MySql, Sistem Penggajian, VisualBasic

\begin{abstract}
The update technology in business processes is indispensable for the Organization, one of the updates that can be upgraded on the payroll. Cooperative Employees of PT Giken Precision Indonesia requires systems that support the payroll process is good for its employees, payroll system that exists on the Employee Cooperative PT Giken Precision Indonesia is still done manually, that is, do pencantatan employee data to manufacture slip salary, this led to the delay in information and data loss. To overcome these problems, required the existence of a new computerized system to improve work efficiency. The methodology used to design a computerized system: analyzing the running system, designing a new system, making the system, and the last test of the system have been made. The application which resulted in the creation of this program
\end{abstract}


is the application of information system of payroll employees using the programming language Visual Basic 2008 and draft database using MySql Server. After going through the stages in accordance with the selected development methods in the implementation of payroll information system that is continuously and have follow-up testing system which consists of testing where this testing using black box testing methods which focus on the functional requirements for software testing and field testing with IE betha processing data as the value of the accuracy of the results of the selection.

Keywords: CrystalReport, Cooperative, MySql, Payroll System,VisualBasic

\section{PENDAHULUAN}

Secara bahasa, kata koperasi berasal dari bahasa inggris yaitu "Cooperation" yang artinya usaha bersama. Koperasi adalah badan hukum yang berdasarkan kekeluargaan yang semua anggotanya terdiri dari perorangan atau badan hukum dengan tujuan untuk mensejahterakan anggotanya.

Koperasi juga diartiakan sebagai badan usaha yang mempunyai anggota yang setiap anggota memiliki tugas dan tanggung jawab masing-masing setiap anggota juga mempunyai hak suara yang sama dalam setiap keputusan yang diambil. (Heryati. 2016). Manfaat dibentuknya koperasi ini adalah untuk membantu para anggotanya dalam memenuhi kebutuhan hidup sehari-hari, dapat menyimpan, meminjam, dan membeli barang secara kredit atau tunai.

Sistem Penggajian merupakan fungsi penting yang menjadi tanggungjawab manajemen koperasi, Sistem Penggajian adalah proses yang menentukan tingkat penggajian pegawai, mengontrol, mengawasi, serta mengendalikan mengendalikan gaji karyawan. Dessler mengatakan (dalam Samsudin, 2006), gaji adalah suatu yang berkaitan dengan uang yang diberikan kepada karyawan. Ia berpendapat bahwa sistem pembayaran dapat dibedakan berdasarkan waktu kinerja dan hasil kinerja. Gaji merupakan bayaran pokok yang diterima oleh seseorang.

Sistem Penggajian adalah sebuah sistem yang dapat menyajikan informasi yang dibutuhkan untuk menghitung penggajian pegawai (Ogujo, 2010: 302). Bisa dikatakan, aplikasi penggajian mencakup dari anggota nilai dari variabel yang dibutuhkan penghitungan sampai menyajikan hasil penghitungan itu sendiri.

Masalah perkembangan teknologi dibidang informasi mendorong setiap pelaku usaha, instansi atau perusahaan untuk tetap mengikuti perkembangannya, terutama berkenaan dengan perkembangan yang ada hubungannya dengan kegiatan bidang usaha tersebut.

Perkembangan teknologi informasi telah memberikan kontribusi yang cukup berarti dalam meningkatkan kegiatan usaha khususnya dalam hal pengolahan data upah kerja karyawan yang memberi dukungan terhadap pengambilan keputusan-keputusan bisnis serta perkembangan teknologi informasi telah memberikan kontribusi yang cukup berarti dalam meningkatkan kualitas kerja karyawan.

Berdasarkan pada uraian diatas pemanfaatan teknologi informasi dalam suatu aktivitas bisnis merupakan hal yang cukup penting. Berkaitan dengan 
pemasalah yang ada pada koperasi karyawan PT Giken Precision Indonesia ini penelitian difokuskan pada masalah pemanfaatan tujuan teknologi informasi yang dapat memberikan dukungan aktif kelacaran sebuah pelaku usaha yang dilakukan pada koperasi karyawan PT Giken Precision Indonesia yang diberi judul "Rancang bangun sistem informasi penggajian karyawan pada koperasi karyawan PT Giken Precision Indonesia Berbasis Visual Basic 2008".

\section{METODE PENELITIAN}

Dalam merancang bangun sistem informasi penggajiaan, penulis menggunakan metode pengumpulam data, metode pengembangan sistem.

SDLC merupakan metodelogi umum dalam pengembangan sistem yang menandai kemajuan dari usaha analisa dan desain.

Menurut Turban (2003), System Development Life Cycle (SDLC) atau Siklus Hidup Pengembangan Sistem adalah metode pengembangan sistem tradisional yang digunakan sebagian besar organisasi saat ini. SDLC adalah kerangka kerja (framework) yang terstruktur yang berisi proses-proses sekuensial di mana sistem informasi dikembangkan.

Metode perancangan sistem yang digunakan dalam penelitian ini yaitu metode SDLC (System Development Life Cycle). SDLC adalah suatu keseluruhan dari sebuah proses perubahan sistem dapat berupa pengembangan atau perubahan system. Metode ini memiliki 5 tahapan, yaitu :

Perancangan (Planning)

Tahap perencanaan adalah tahap awal pengembangan sistem yang mendefinisikan perkiraan kebutuhankebutuhan sumber daya, seperti : perangkat fisik, metode dan anggaran yang sifatnya masih umum. Didalam tahap ini juga dilakukan langkahlangkah berupa : mendefinisikan masalah, menentukan tujuan sistem, mengidentifikasi kendala-kendala sistem dan membuat studi kelayakan.

Analisis (Analysis)

Tahap analisis ini merupakan tahap penelitian atas sistem yang berjalan dengan tujuan untuk merancang sistem yang baru dengan menggunakan tools atau alat bantu DFD (Data flow Diagram) dengan software Microsoft Visio, DFD membantu dalam analis sistem untuk meringkas informasi tentang sistem, mengetahui hubungan antar sub-sistem, membantu perkembangan aplikasi secara efektif dan sebagai alat komunikasi yang baik antara pemakai dan analis sistem, karena dapat menggambarkan sejumlah batasan untuk pengembangan alternatif sistem fisik

\section{Desain (Design)}

Tahap Design yaitu tahap dalam menentukan proses fungsional yang diperlukan oleh sistem baru dengan tujuan memenuhi kebutuhan user dengan alat bantu DFD dengan software Microsoft Visio. Proses fungsional berorientasi pada alur data dengan konsep dekomposisi dapat digunakan untuk penggambaran analisa maupun rancangan sistem yang mudah dikomunikasikan oleh profesional sistem kepada pemakai maupun pembuat program menerjemahkan syarat kebutuhan ke sebuah perancangan perangkat lunak yang dapat diperkirakan sebelum dibuat pengkodean.

Testing dan Implementasi (Testing And Implementation)

Penelitian ini menggunakan pengujian Blackbox Testing yaitu 
metode uji coba yang memfokuskan kepada kebutuhan softaware. Metode pengujian Blackbox Testing berusaha untuk menemukan kesalahan dalam beberapa kategori, diantaranya fungsifungsi yang salah atau hilang, kesalahan dalam interface, kesalahan dalam struktur data atau akses database eksternal, dan kesalahan performa. Oleh karena itu, penulis menggunakan metode pengujian Blackbox Testing sehingga dapat diketahui apakah sistem sesuai dengan apa yang dibutuhkan oleh Stakeholder. Tahap implementasi adalah tahap dimana rancangan sistem yang dibentuk menjadi suatu kode (program) yang siap untuk dioperasikan, audit sistem, penjagaan, perbaikan dan pengembangan sistem.

Pemeliharaan (Maintenance)

Setelah melakukan pengujian dan implementasi terhadap sistem baru, tahapan selanjutnya adalah melakukan pemeliharaan dan pengembangan sistem. dimana pada tahap ini sistem secara sistematis diperbaiki dan ditingkatkan.untuk melakukan pengembangan sistem, penulis memerlukan alat bantu pengembangan sistem, berikut ini merupakan alat bantu dalam pengembangan sistem yang di butuhkan.

\section{Microsoft Visual Basic 2008}

Microsoft Visual basic 2008 adalah salah satu bahasa pemrograman komputer tingkat tinggi. Bahasa pemrograman adalah perintah-perintah yang dimengerti oleh komputer untuk melakukan tugas-tugas tertentu bahasa pemrograman visual basic 2008 dikembangkan oleh Microsoft, merupakan salah satu bahasa pemrograman yang Object Oriented Program (OOP) atau pemrograman yang berorientasi pada Object. Kata
"Visual" menunjukkan cara yang digunakan untuk membuat Graphical User Interface (GUI).

\section{MySQL}

MySQL adalah sebuah perangkat lunak sistem manajemen basis data SQL (database management system) atau DBMS yang multithread, multi-user, dengan sekitar 6 juta instalasi di seluruh dunia. MySQL AB membuat MySQL tersedia sebagai perangkat lunak gratis dibawah lisensi GNU General Public License (GPL), tetapi mereka juga menjual dibawah lisensi komersial untuk kasus-kasus dimana penggunaannya tidak cocok dengan penggunaan GPL.

MySQL sebenarnya merupakan turunan salah satu konsep utama dalam database sejak lama, yaitu SQL (Structured Query Language). SQL adalah sebuah konsep pengoperasian database, terutama untuk pemilihan atau seleksi dan pemasukan data, yang memungkinkan pengoperasian data dikerjakan dengan mudah secara otomatis.

\section{XАMPP}

Software yang satu ini bernama $X A M P P$ yang merupakan singkatan dari Apache, MySQL, dan Perl sedangkan huruf "X" dimaksudkan sebagai suatu software yang dapat dijalankan di empat OS utama seperti Windows, Mac OS, Linux dan Solaris. Istilah ini seringkali disebut dengan cross platform (software multi OS).

Sesuai dengan namanya software yang satu ini merupakan gabungan dari beberapa software dengan fungsi yang sama yakni menunjang para pembuat web yang menginginkan adanya web server sendiri di PC atau laptopnya. Software ini juga berlisensi $G N U$ dan 
dapat didownload secara gratis di internet mengingat peran vital yang dimilikinya terutama bagi pembuat web pemula.

Software XAMPP didirikan oleh suatu perusahaan bernama Apache Friends. Dengan adanya beberapa tools pemrograman seperti MySQL, PHP dan Perl yang dimilikinya tentu mengindikasikan jika anda menekuni salah satu atau semuanya berarti harus memiliki software yang bernama XAMPP ini. Maksud dari Apache yakni selain mengindikasikan nama pengembangnya juga merupakan suatu software yang menghadirkan web server pada komputer anda layaknya web server sesungguhnya.

\section{Kerangka Kerja}

Untuk membantu dalam penyusunan penelitian ini, maka perlu adanya susunan kerangka kerja (frame work) yang jelas tahapan-tahapannya. Kerangka kerja ini merupakan langkahlangkah yang akan dilakukan dalam penyelesaian masalah yang akan dibahas. Adapun kerangka kerja penelitian yang di gunakan seperti terlihat pada tabel dibawah ini :

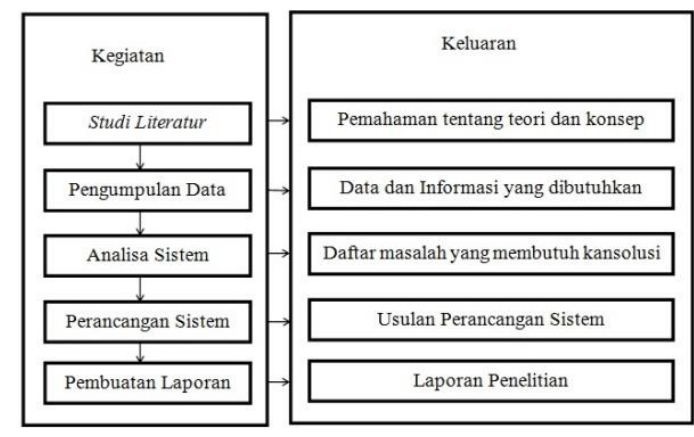

Gambar Kerangka Kerja

Berdasarkan kerangka kerja penelitian yang telah digambarkan di atas, maka dapat diuraikan pembahasan masing-masing tahap dalam penelitian adalah sebagai berikut :

\section{Studi Literatur}

Pada tahap ini dilakukan pencarian landasan-landasan teori yang diperoleh dari berbagai buku, jurnal dan juga internet untuk melengkapi perbendaharaan konsep dan teori, sehingga memiliki landasan dan keilmuan yang baik dan sesuai.

\section{Pengumpulan Data}

Pada tahap ini dilakukan proses pengumpulan data dengan metode wawancara dan observasi untuk melakukan pengamatan dan analisa terhadap penggajian karyawan pada koperasi karyawan PT Giken Precision Indonesia sehingga mendapatkan data dan informasi yang dibutuhkan oleh peneliti.

\section{Analisa Sistem}

Pada tahap ini dilakukan identifikasi masalah pada sistem yang sedang berjalan. Dengan demikian, diharapkan peneliti dapat menemukan kendalakendala dan permasalahan yang terjadi pada penggajian karyawan koperasi karyawan PT Giken Precision Indonesia sehingga peneliti dapat mencari solusi dari permasalahan tersebut.

\section{Perancangan Sistem \\ Pada tahap ini merupakan sekumpulan aktifitas yang} menggambarkan secara rinci bagaimana sistem akan berjalan. Hal ini bertujuan untuk menghasilkan produk perangkat lunak yang sesuai dengan kebutuhan user. 
5. Pembuatan Laporan

Pada tahapan ini dilakukan pembuatan laporan yang disusun berdasarkan hasil pembautan perangkat lunak dengan menggunakan teknik pengumpulan data sehingga menjadi laporan penelitian yang dapat memberikan gambaran secara utuh tentang sistem yang sedang dibangun.

\section{RANCANGAN SISTEM}

Berikut ini adalah rancangan sistem yang dibuat oleh peneliti yaitu sebagai berikut:

\section{ERD (Entity Relationship Diagram)}

Entity Relationship Diagram (ERD) digunakan untuk memodelkan struktur data dan hubungan anatar data, dalam memggambarkanya mengunakan beberapa notasi dan simbol-simbol ERD.

Menurut Brady dan Loonam (2010), Entity Relationship Diagram (ERD) merupakan teknik yang digunakan untuk memodelkan kebutuhan data dari suatu organisasi, biasanya oleh System Analys dalam tahap analisis persyaratan proyek pengembangan sistem.

Diah Puspitasari (2015) ERD dikembangkan berdasarkan teori himpunan dalam bidang matematika. ERDdigunakan digunakan untuk pemodelan basis data relasional. Sehingga jika penyimpanan basis data menggunakan OODBMS maka perancangan basis data tidak perlu menggunakan ERD.

Menurut Diah Puspitasari (dalam Simarmata, 2007:107) menyatakan bahwa "derajat relasi adalah sejumlah entitas yang berhubungan dengan hubungan. Hubungan n-ary adalah format yang umum untuk derajat $n$.
Kasus khusus adalah seperti biner dan ternary, dimana derajatnya adalah 2 dan 3 secara berturut-turut.

ERD atau Diagram antar Entitas adalah suatu diagram yang menggambarkan hubungan objek data yang disimpan yang ada dalam suatu sistem secara konseptual, dan dibuat secara agregasi. Agregasi merupakan proses menghubung-hubungkan sebuah kumpulan relasi dengan suatu kumpulan entitas. Caranya yaitu dengan membuat sebuah relasi baru. Relasi inilah yang nantinya akan secara langsung menghubungkan kumpulan relasi dan kumpulan entitas. Hal ini sangat bisa dilakukan karena pada dasarnya relasi dapat terbentuk karena relasi tersebut mengandung unsur dari relasi lain.

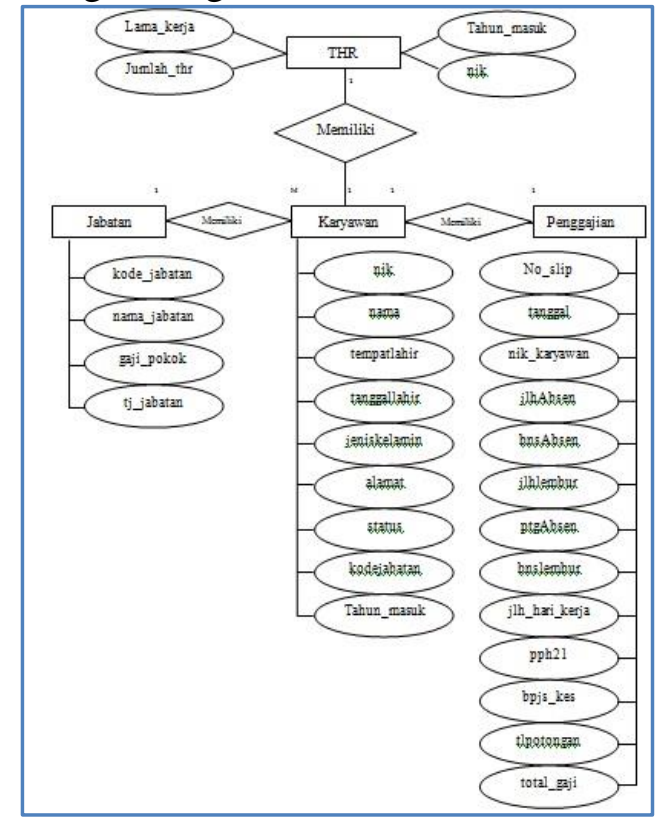

\section{Gambar Diagram Hubungan Antar Entitas}

\section{Context Diagram (Diagram Konteks)}

Context Diagram adalah diagram yang menggambarkan hubungan antara entitas eksternal dengan sistem. Dimana data yang diinputkan oleh bagian entitas 
eksternal akan diproses di dalam sistem dan akan menghasilkan laporan yang diinginkan oleh eksternal tersebut. Untuk lebih jelasnya dapat dilihat pada gambar berikut ini :

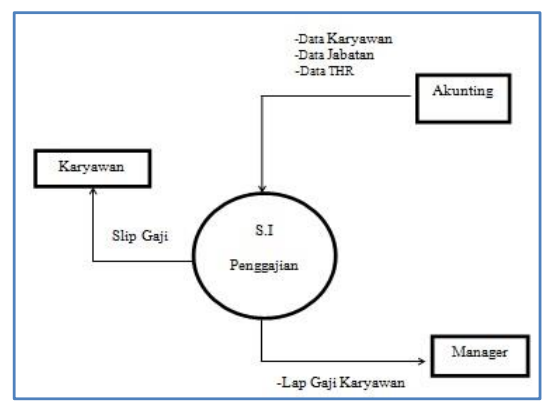

Gambar Context Diagram

\section{Rancangan Sistem Yang Diusulkan}

Rancangan sistem merupakan rancangan form pada program yang telah dibuat oleh peneliti berserta format data didalamnya adalah sebagai berikut:

1. Tampilan Form Login

Form login diisi berdasarkan id dan password yang telah dibuat, jika sesuai dengan data yang ada maka akan masuk pada tampilan menu utama

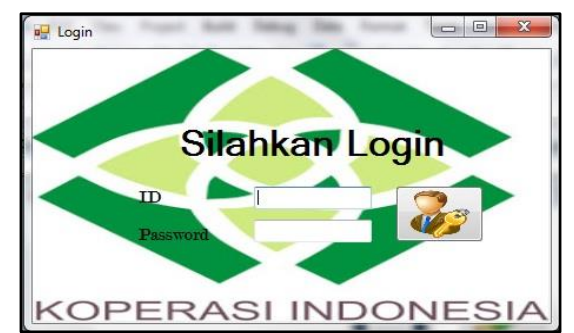

\section{Gambar Tampilan Form Login}

2. Tampilan Form Menu Utama

Form menu utama terdiri dari beberapa menu diantaranya form master, proses, laporan gaji dan keluar.

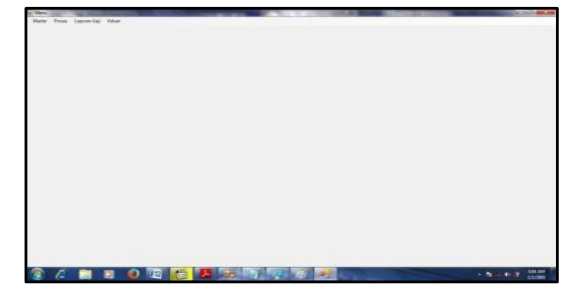

\section{Gambar Tampilan Form Menu} Utama

\section{Tampilan Form User}

Form user dapat digunakan untuk menambah user dan status user, dapat menghapus, dan mengubah status user.

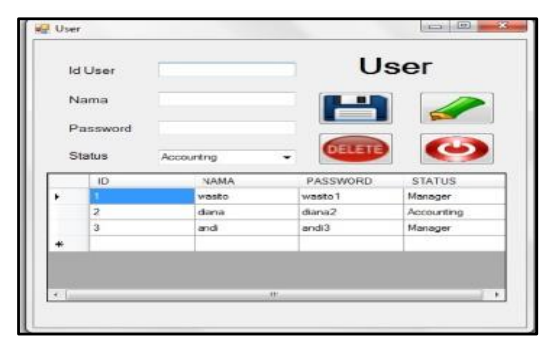

\section{Gambar Tampilan Form User}

4. Tampilan Form Data Karyawan Pada form data karyawan user dapat menambah, mengubah, dan menghapus data karyawan.

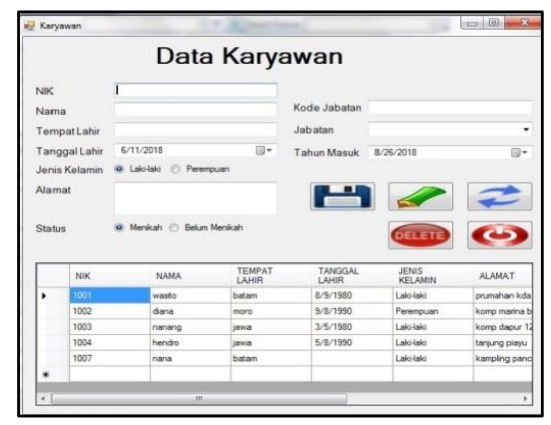

\section{Gambar Tampilan Form Data Karyawan}

\section{Tampilan Form Jabatan}

Pada form jabtan user dapat menambah jabatan karyawan sesuai jabatan yang dan 
ISSN 2338-1523

E-ISSN 2541-576X

Volume 6 No. 2

Desember 2018

menghapus jabatan yang tidak lagi digunakan.

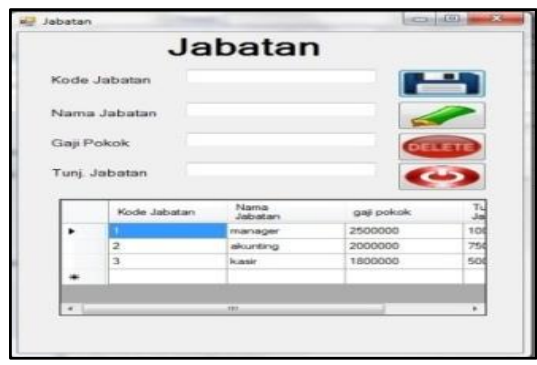

Gambar Tampilan Form Jabatan

6. Tampilan Form THR

Pada from thr user dapat menambah data thr sesuai dari data karyawan dan jabatan yang ada.

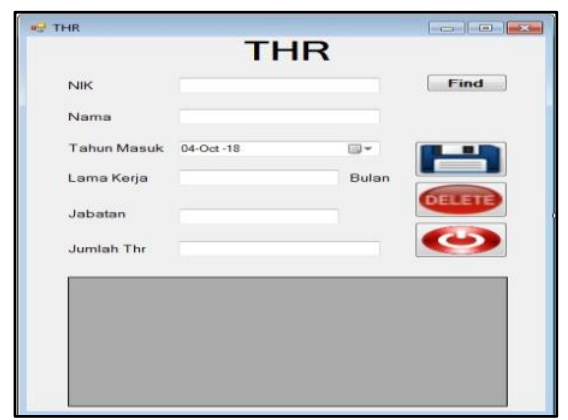

Gambar Tampilan Form THR

7. Tampilan Form Penggajain

Pada from penggajian user dapat mengisi berdasarkan nik karyawan sehingga akan terisi sendiri sesuai dengan data karyawan dan jabatan yang sudah ada pada database.

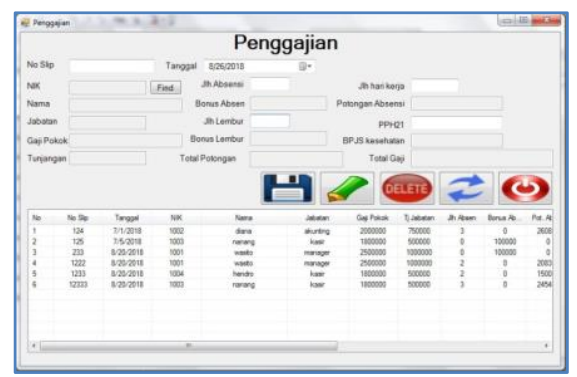

Gambar Tampilan Form Penggajian

8. Tampilan Form Laporan
Pada form laporan user dapat mencetak laporan dan slip gaji karyawan

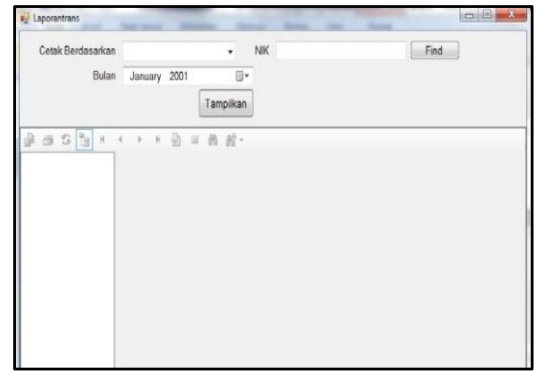

\section{Gambar Tampilan Form Laporan}

9. Tampilan Slip gaji

Ini merupakan tampilan slip gaji yang akan diterima karyawan yang dicetak user pada form laporan.

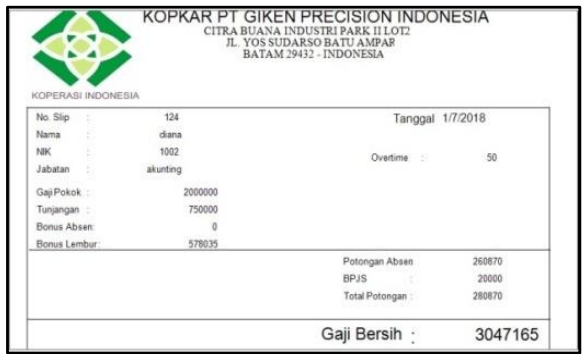

Gambar Tampilan Slip Gaji

10. Tampilan Laporan Gaji Ini merupakan tampilan laporan gaji yang akan diterima manager yang dicetak user pada form laporan.

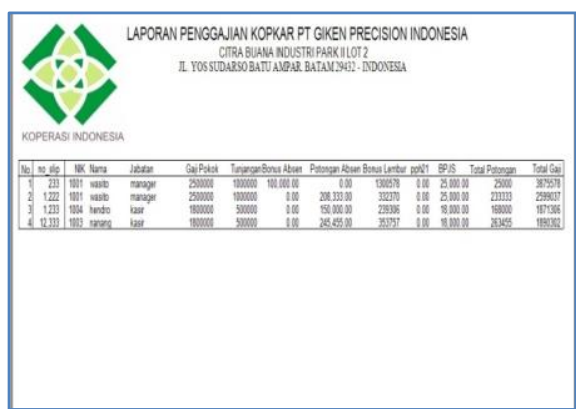

Gambar Tampilan Laporan Gaji 


\section{KESIMPULAN}

Perancangan sistem penggajian karyawan pada Koperasi Karyawan PT Giken Precision Indonesia berbasis Visual Basic 2008 ini bertujuan untuk mempermudah bagian akunting dalam menangani proses penghitungan gaji karyawan dan juga untuk mempermudah pihak koperasi untuk mengetahui laporan penggajian.

Sistem informasi penggajian berbasis Visual Basic 2008 ini mampu untuk memberikan efektif kerja. Secara garis besar, berdasarkan hasil perancangan dan pembuatan aplikasi untuk system informasi penggajian berbasis Visual Basic 2008 pada Koperasi Karyawan PT Giken Precision Indonesia yang telah dilakukan, dapat disimpulkan hal-hal sebagai berikut :

a. Sistem komputerisasi dapat mempercepat pengolahan data penggajian dan pembuatan laporan gaji karyawan pada Koperasi karyawan PT Giken Precision Indonesia.

b. Sistem komputerisasi dapat meningkatkan pelayanan penggajian kepada semua karyawan yang bekerja pada Koperasi karyawan PT Giken Precision Indonesia

c. Dengan adanya sistem meminimalkan kesalahan yang dilakukan secara tulis tangan seperti pencatatan, perhitungan, pengecekan ataupun proses pemeriksaan yang membutuhkan ketelitian.

\section{UCAPAN TERIMA KASIH}

Peneliti mengucapkan terima kasih kepada berbagai pihak yang telah membantu dalam menyelesaikan penulisan ini. Terima kasih kepada Koperasi Karyawan PT Giken Precision Indonesia yang telah meluangkan waktunya untuk peneliti melakukan penelitian ini dan telah bersedia di wawancarai dan terakhir terima kasih kepada TIM LPPM Sekolah Tinggi Manajemen Informatika dan Komputer GICI.

\section{DAFTAR PUSTAKA}

Arief, M.Rudyanto, 2011. Pemrograman Web Dinamis Menggunakan PHP dan MYSQL. Andi, Yogyakarta.

Brady, M., \& Loonam, J. (2010). Exploring the use of entity-relationship diagramming as a technique to support grounded theory inquiry. Bradford: Emerald Group Publishing.

Heryati. Agustina. (2016). Pengaruh kompensasi dan disiplin kerja terhadap loyalitas karyawan di Departemen operasi pupuk Sriwidjaja Palembang. Jurnal Ilmiah Ecoment Global (1) agust: 56-75

Puspitasari, Diah. (2015). Rancang Bangun Sistem Informasi Koperasi Simpan Pinjam Karyawan Berbasis Web. Bekasi : Jurnal Pilar Nusa Mandiri Vol. XI, No.2 September 2015.

Ojugo, Clement. 2010. Practical Food and Beverage Cost Control. Delmar Cengage Learning: New York.

Selviana, Elvi. (2013). "Perancangan Sistem Informasi Penggajian Pegawai Berbasis Web pada Kelurahan Cikokol Tanggerang" Skripsi, Jurusan Informasi, Taggerang.

Samsudin, Sadili, H. 2006. Manajemen Sumber Daya Manusia Penerbit PT. Pustaka Setia, Bandung. 
ISSN 2338-1523

E-ISSN 2541-576X

Volume 6 No. 2

Desember 2018

Sutabri, Tata. 2012. Analisis Sistem Informasi. Andi Offset : Yogyakarta.

Sutabri, Tata.2012. Konsep sistem Informasi. Andi Offset:Yogyakarta

Sutarman. 2012. Buku Pengantar Teknologi Informasi. Jakarta: Bumi Aksara

Turban, Efraim et al. 2003. Introduction to Information Technology, 2nd Edition. John Wiley \& Sons, Inc. New York. USA. 